\title{
The Ne Bis In Idem Principle in Tax Law: European and Italian Frameworks
}

\author{
Stefania Lotito Fedele \\ University of Bari, Faculty of Law, Italy \\ stefania.lotitofedele@uniba.it \\ https://orcid.org/0000-0003-0108-9863
}

Received: 6. 1. 2020

Accepted: 19. 3. 2020

\section{ABSTRACT}

In the national and supranational legal area, the need to address the ne bis in idem principle is justified by the growing interest aroused by the most recent pronouncements of the European Courts. The principle prohibits anyone who has already been acquitted or convicted in a previous trial from being tried again. Moreover, it has become a fundamental right enshrined in the European Convention on Human Rights and the Charter of Fundamental Rights of the EU. The interest in the issue also derives from the need to understand whether the approach of the Italian legal system - or any other similar national order - can be considered compliant with European tax law and case law, based on the definitions of criminal and tax offences. Thus, talking about a European legal space means rethinking the idea of punitive power in a dimension that tends to be 'solidarity-based'. The State can consider itself impervious to repressive demands from outside but is instead called to cooperate actively to safeguard its own guarantees. The traditional self-referential conception of criminal repression effectively summarised in the expression 'punitive sovereignty' gives way to an idea of jurisdiction that draws directly from the principle of mutual recognition. In this scenario, the profile of the protection of the individual from the risk of a duplication of the exercise of punitive power for the same fact in different states assumes the role of the first magnitude. Hence, there is a need to act on two levels at the same time: to seek solutions aimed at resolving possible conflicts of jurisdiction (prohibition of competing prosecutions for the same fact), and to attribute, within each Member State, preclusive effects to the previously judged foreigner (ne bis in idem).

Keywords: European tax law and case law, fiscal administration, Italy, ne bis in idem principle 


\section{Introduction to the system}

With the fall of the Berlin Wall, criminal law has ceased to be a pure state phenomenon. The collapse of the barriers that marked the division into blocks of the international community was indeed accompanied by a vast process of globalisation of the law, which affected the entire legal system, particularly the criminal law.

However, the process of globalization of criminal law has assumed distinctive traits, characterised by a marked asymmetry. On one hand, there has been a centralisation of criminal law. On the other hand, there is an opposing trend to limit this process, under the aegis of human rights.

Both these phenomena tend towards the principles of sovereignty, territoriality, and legality, which constitute the traditional triad of modern criminal law. Moreover, the crisis of state sovereignty reveals itself in the loss of absoluteness of national punitive power: la loi n'a plus tous les droits.

Nowadays, a complex net has replaced the traditional pyramidal structure of the sources of law. The national legislative monism ratified in the nineteenth-century codes is undermined by different types of normative acts: directives, regulations, framework decisions and community sources on one hand and international covenantal laws on the other hand.

In this historical, political and cultural context, the principle of ne bis in idem ceases to be a purely national phenomenon to become an international issue. It constitutes the epiphenomenon of a process that is characterized by the presence of two contradictory imperatives.

On one hand, the greater mobility of individuals and the rise of international crime, brought by the fall of many frontiers, has led the States to adopt extraterritorial criteria for the application of jurisdiction as well as to widen the scope of the criminal penalty.

On the other hand, the interdiction of both pursuits and penalties is justified by the need to respect the fundamental rights of individuals in the framework of national criminal policies, which are increasingly less impenetrable and conditioned by the demands of the international community.

The Latin phrase ne bis in idem means "not twice for the same thing". Therefore, no one can be tried more than once for the same fact. This principle has been known since the time of Roman law and it has been applied in all types of trials: civil, criminal and administrative ones. Contemporary, this principle represents one of the most evident indicators of an advanced stage of legal civilization.

The ne bis in idem principle provide that a person cannot be criminally prosecuted or punished twice for the same offense. That fundamental right is recognized both by the Charter of Fundamental Rights of the European Union (art. 50) and by the European Convention on Human Rights (Protocol No. 7, 
art. 4 to the European Convention for the Protection of Human Rights and Fundamental Freedoms).

\section{Starting point}

\subsection{Theoretical background}

This contribution finds its roots in very recent judgments of the ECtHR (e.g. first $15^{\text {th }}$ November 2016, A and B v. Norway, ${ }^{1}$ n. 24130/11 and 29758/11, and then, $18^{\text {th }}$ May 2017 , J. J. v. Iceland ${ }^{2}$ ). These sentences raised very important debates on the fiscal system and the relationship between the general values of the EU law and the national constitutional values.

Indeed, the Grande Chambre established that whether a final sentence has been issued against a defendant who has already been fined (with a surtax) by the tax administration, the penal trial does not violate the conventional principle of ne bis in idem. What is the conditio sine qua non? There must be a "sufficiently close connection in substance and time".

Moreover, in the Icelandic case, the ECtHR confirmed the same principle: it restated the necessity of executing the two proceedings (administrative and penal) at the same time to avoid a duplication of the investigation activity regarding the evidence collection. Thus, the same Court completely changed what was declared in this regard up to now, creating further confusion.

Before examining the above-mentioned cases, it may be worth spending a little time thinking about what is objectionable about Double Jeopardy in the context of tax cases. Article 4 of the Seventh Protocol of the ECtHR prohibits a person being "tried or punished again in criminal proceedings" for an offense for which he has already been finally acquitted or convicted. Thus, it covers both situations where an individual is punished twice and where the individual is tried twice (or is liable to be tried or punished twice).

In the tax context, it is not unusual for multiple consequences to flow from a taxpayer's failure to comply with tax laws: the individual will be liable to pay the additional tax, plus interest, plus administrative penalties (generally assessed by the tax authorities, but subject to review or appeal). More than one tax might be at issues, such as income tax, social security taxes, and VAT.

In an ideal world, a taxpayer would face a single set of proceedings with a cumulative outcome reflecting the severity of the taxpayer's conduct.

The General Advocate of the Court of Justice also pointed out that the ne bis in idem principle is an integral part of the primary law of the Union, and as such prevails over the national rules of the Member States.

Therefore, if the rules are incompatible with the universal right of the ne bis in idem principle, the national Court or the competent administrative authori-

1 ECtHR, Grande Chambre, 15 November 2016, A e B. v. Norway, App. n. 24130/11 and 29758/11.

2 ECtHR, Sec. I, 18 May 2017, Jòhannesson and others v. Iceland, App. n. 22007/11. 
ties will have to file the pending proceedings, without negative consequences for the person who has already been prosecuted or sanctioned in another criminal or administrative proceeding.

Finally, on $20^{\text {th }}$ March 2018, the CJEU filed three judgments relating to different facts but having the same subject - Cases C-524/15, C-537/16, C-596/16, C-597/16 - in which the Court has mostly confirmed the continuity of the duplication of proceedings envisaged by Italian law.

Based on those considerations, the statements of the Grande Chambre (regarding the Norway case) are likely to be relevant for all those Countries that have ratified the Seventh Protocol, in which tax matters can be part of criminal law and provide substantial administrative fines or surcharges.

\section{Key issues and method}

Efficiency, in the context of this work, is understood as the capacity of the internal criminal and administrative procedures to generate decisions containing a double penalty. It also seems necessary to follow up the questions below:

1. Compatibility between the Italian double track system and European conditions: a) What interpretation should be given to the ne bis in idem principle to ensure its correct application? b) What limits must be recognized (and respected) for the coexistence between the (European) ne bis in idem system and the (Italian) double-track penalty system? c) Can the Italian legal system comply with the requirements of the $A$ and $B$ v. Norway judgment?

2. What is the European action? Eliminate duplication in the same legal situation and excessive sacrifices, including in terms of the burden of proof. Therefore, according to the ECtHR, a considered circulation of data and evidence during the tax and criminal procedure phase could only be achieved through preventive cooperation between national and supranational authorities: a) Are National Authorities prepared to cooperate with European authorities?

First, it is useful and necessary to briefly describe the principle of ne bis in idem to better understand the birth of the double (European) track and the effect it has on the Italian system.

Clearly, in the latest years, the relationship between the national and supranational judges has become important, given the strong influence on the production and interpretation of the domestic law. Specifically, the fiscal matter always raised a discussion about the interpretation and application of the supranational law regarding the inviolable values of the Italian Constitution.

Indeed, the tax system has been ruled for a long time by the overlapping of the criminal and administrative penalty (i.e. double track) which was partially modified by article 19 of the legislative decree No. 74/2000. ${ }^{3}$ The principle of

3 Legislative Decree no. 74 of 2000 concerns violations of income tax and VAT, with the exclusion of taxes of a different nature. 
specialty, introduced by the Art.19, provides the choice of the special norm over the general norm, to avoid the duplication of the procedures and penalties. By doing so, the Italian legislator has overcome the antinomy between two different forms. ${ }^{4}$

Nowadays, after seventeen years, it seems that the double-jeopardy rule has never really disappeared, determining an obscure return to the past. Nevertheless, beyond the rise of relevant doubts on its rationality, the double-track system is in contrast with the principle of ne bis in idem, declared by both the art. 50 EUCFR and art. 4, Prot. n. 7, ECHR.

In its general structure, this decree has also taken a form typical of the techniques of international regulatory instruments. In fact, Title I consists of a single article containing the "definitions": the intent is to provide a synthetic perspective of the main legal concepts whose knowledge, on the one hand, represents an inescapable premise for the correct interpretation of the single incriminating provisions, on the other hand, allows to quickly detect the boundaries of concepts sometimes complex as they relate to substantive tax law.

The technical-legal instruments, through which the legislator intended to convey preventive and punitive responses appropriate to the consistency of the evasive phenomenon, represent an indispensable prerequisite of the above-mentioned regulations, contributing to determine the crisis of the 'double-track' tax sanctions.

These instruments can be identified in the first instance in Articles 19, 20 and 21 of Decree $74 / 2000$.

Thus, the legislator perfected an overall system already outlined by Legislative Decree No. 472 of 18 December 1997, where a certain 'qualitative analogy' between administrative and criminal offence is highlighted and where the former is 'constructed' and regulated in its general connotations in substantially criminal terms (at least about the criteria of imputation and techniques of quantification of the sanction).

4 It should be pointed out, first of all, that the principle of speciality, to which Article 15 of the Criminal Code refers (with regard to the hypothesis of several criminal laws or several provisions of the same criminal law regulating "the same matter") on the one hand aims at implementing the principle of ne bis in idem and, on the other hand, serves to identify and regulate an apparent concurrence of incriminating rules which is opposed to the actual or real concurrence and the formal concurrence of the same. In fact, there is a uniqueness of crime, since the incriminating rule applicable in the specific case is the only one.

It should be pointed out, first of all, that the principle of speciality, to which Article 15 of the Criminal Code refers (with regard to the hypothesis of several criminal laws or several provisions of the same criminal law regulating "the same matter") on the one hand aims at implementing the principle of ne bis in idem and, on the other hand, serves to identify and regulate an apparent concurrence of incriminating rules which is opposed to the actual or real concurrence and the formal concurrence of the same. In fact, there is a uniqueness of crime, since the incriminating rule applicable in the specific case is the only one.

In the second place, it is worth remembering that the same Article 19 is followed by Articles 20 and 21 , which, together with the first, contribute to delineate the overall system in which the specialty criterion operates, with the specification of the concrete operative modalities of the same.

Article 20, in fact, provides that the administrative assessment procedure and the tax trial cannot be suspended due to the pending criminal proceedings concerning the same facts or facts on whose assessment the relative definition depends. In the same way, and pursuant to Articles 3 and 479 of the Criminal Code, the criminal trial cannot be suspended pending the definition of the tax trial, given the probative limits relative to this second trial.

Thus, the double-track system is composed of two main corollaries: on the one hand, the tax judgement has no effectiveness in the criminal trial, unlike what happened before the Legislative Decree No. 429 of 1982, when the rule of the 'tax preliminary ruling' was in force; on the other hand, and correlatively, not even the criminal judgement has effectiveness in the tax trial, even if the extra-penal ineffectiveness of the first seems to derive from Article 654 of the Criminal Code, in relation to the probative limitations to which the second trial is submitted. With regard to Art. 21, the Legislator has evidently intended to make a balance between the application of the principle of specialty and the principle of the double track - as transposed by the previous Articles 19 and 20 - and the need not to determine an excessive expansion of the time of carrying out, in concrete terms, the administrative activity of ascertaining the tax evaded and of imposing the connected non-criminal sanctions. 
Also, except in rare cases, the Court of Cassation does not agree with the ECtHR vision. Indeed, the Judges do not reveal a contrast among the principles cited above but do confirm the possible existence of a penal/administrative double track. In fact, with the legislative decree N. 158 of 2015, the Italian legislator did not feel the need - neither the duty - to offer a solution to the evident violation of the principle of ne bis in idem, as suggested by the ECtHR. On the other hand, the ECtHR has often declared the conventional illegitimacy of the penal/administrative double track, even if related to the punitive tax-related system of other States (as in the art. 4, Prot. n. 7, ECHR).

In this context, it appears relevant to mention the most important ECtHR case-law in the field of ne bis in idem, i.e. 8th June 1976 - Engel vs. the Netherlands, 10th February 2009 - Zolotukhin vs. Russia, 4th March 2014 - Famous case of Grande Stevens vs. Italy, 27th November 2014 - Lucki Dev vs. Sweden, and 10th February 2015 - Kiiveri vs. Finland; CGUE: Akerberg Fransson vs. Sweden): these judgments are the basic guidelines for the ongoing debates.

\section{Results}

\subsection{European and Italian point of view. Similarities and differences}

The analysis of these European case-law has been relevant in this context because they entailed certain reflections on the Italian penalty system. Indeed, the remarkable jurisprudential and doctrinal debate on the ne bis in idem principle has finally reached the Constitutional Court, thanks to the Court of Monza.

The case concerned the owner of an individual company who was sanctioned in a final judgment first with an administrative penalty and then he was prosecuted in a criminal proceeding (for the same year and the same taxes) for the crime of omitted revenue declaration pursuant ex-art. 5 of the legislative decree No. 74 of 2000.

The judge of Monza, after having recalled the jurisprudence of the supranational Courts about matters regarding the ne bis in idem violation, turns to the Constitutional Court and he points out that the administrative penalties that were given in this case:

- They were criminal penalties;

- The historical fact at the base of the two proceedings was the same;

- On one hand, the Italian system provides a remedy to the double-track judicial system;

- On the other hand, the ne bis in idem principle, as required from the international jurisprudence, is not always guaranteed.

While the ECtHR had sometimes deemed compliant to art. 4, Prot. 7, ECHR, the Constitutional Court declares that the criterion of "sufficiently close con- 
nection in substance and time" could not be viewed as a general principle since it had only been applied in specific cases. Thus, it recognizes the imperative nature of the conventional ne bis in idem and that its effects cannot be mediated by personal considerations of the national judges. ${ }^{5}$

Indeed, according to the constitutional judges, these criteria could be applied to the relationship between tax and criminal proceedings only if (as it is the case in Italian law) both the administrative and criminal judges are required to independently assess the facts. Therefore, the substantial and temporal relationship between the two proceedings would not be enough condition for the European case law, to effectively exclude the ne bis in idem principle.

However, with the Norway case, the Court of Strasbourg has embarked on a new development of the subject, trying to meet the interpretative difficulties created as a result of the strict interpretation of Art. 4, Prot. 7.

The Constitutional Court provides that the ECtHR (with the Norway case) recognizes that the principle of ne bis in idem principle ceases to act as an imperative rule, but its application is subordinated to the assessment by the judge about the existence of a "sufficiently close connection in substance and time" of the two proceedings.

In other words, it can be stated that we have moved from the prohibition imposed on the States to start two independent proceedings for the same unlawful act, to the faculty of coordinating, in time and substance, these procedures, so that they can be considered as a unique and adequate punitive answer.

In conclusion, the Court states that the new meaning of the law, introduced by the Norway case, involves the return of documents to the National Court to be assessed on the issue of constitutional legitimacy. In fact, if the national court considers that the criminal proceedings are connected, in substance and time, to the tax proceedings (so as not to constitute a conventional ne bis in idem) there would be no need to introduce any rule, which imposes not to proceed for the same fact.

\section{Discussion and conclusion: what are the most appropriate solutions today?}

For some years now, especially since the well-known Grande Stevens judgment of the ECtHR, the question of the possible violation of the principle of ne bis in idem, as conceived by national case law, has been raised in doctrine and jurisprudence based on the already mentioned rules contained in Art. 4, Prot. 7, ECHR and Art. 50 EUCFR. The problem relates to the compatibility of the dual-track system of sanctions with the transnational regulatory system as interpreted by the case-law of the EDU and the European Court of Justice. And - at least in the abstract - it affects, transversally, all tax crimes that punish

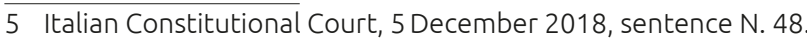


conduct substantially superimposable on those punished also at the administrative level.

The issue is of extreme importance, as demonstrated by the fact that - following numerous rulings by the Strasbourg and Luxembourg Courts (relating, in large part, to the subject of tax offenses) - it is precisely the Italian judges who have in recent years raised multiple preliminary questions (of interpretation before the European Court of Justice, and constitutional legitimacy).

The contrast derives in particular - and in a nutshell - from a series of principles, by now more than consolidated in transnational jurisprudence (but not yet fully transposed by Italian jurisprudence), through which the ECHHR and the European Court of Justice have reconstructed - in a binding way for national judges - the content of the ne bis in idem; content that, with all evidence, is decidedly wider than the restricted scope of criminal proceedings and, in particular for the Italian system, than the perimeter outlined by Article 649 of the Italian Criminal Code.

As repeatedly highlighted in the body of the contribution, the recent ruling of the Grand Chamber of the ECtHR (judgment of November 15, 2016) regarding the Norwegian tax penalty system has had a far from marginal - and in a restrictive sense - impact on the boundaries of ne bis in idem, significantly weakening the problem of compatibility between double track sanctions and prohibition of bis in idem.

Thus, this principle, originally confined within the narrow limits of a national-territorial dimension, has today become a fundamental right of the European citizen, deploying its effects in the territory of all the member states of the European Union. To the already mentioned prohibition of double proceedings for the same fact before the judicial authorities of the same State (socalled internal dimension) corresponds the prohibition of double proceedings for the same fact before the judicial authorities of different States (so-called transnational dimension), a sphere which is expressly contemplated in supranational sources.

The ECtHR and the European system, centred on the Charter of Fundamental Human Rights, seem to move in the same direction, although with the inevitable differences imposed by the different legal contexts in which the two Courts are located. Both impose a reflection on the domestic system focussed on the double track and on the principle of specialty, a system which as interpreted by the Court of Cassation and, last but not least, as seen by the Constitutional Court itself - seems not entirely consistent with supranational approaches.

Rebus sic stantibus, from the analysis carried out so far, the situation of immobility appears rather evident.

On the one side, a jurisprudence too cautious and shrewd to affirm the superiority of the right to ne bis in idem on the internal sanctioning mechanisms; on the other side, an unarmed legislator, or rather, absent, who continues to 
renounce to furnish answers and concrete solutions to the multiple problems of compatibility between the internal regulations and the aforementioned fundamental right ${ }^{6}$ (Scaroina, 2015, pp. 2920-2921).

Also, the pronouncements of the internal Courts have not failed to underline the necessity of a legislative intervention on the subject, which would finally bring to a conclusion the much desired and spurred - and, at this point of the path, one could say almost utopian - overall reorganization of the relations between administrative and criminal offenses.

The Constitutional Court has chosen itself not to intervene through a strong solution (as could have been the declaration of constitutional illegitimacy of the double-track sanctions, as happened in France), thus turning off the last lights of hope turned on in doctrine (Fatta, 2017, p. 23). ${ }^{7}$

The legislator should undoubtedly have made a greater commitment to really protect, and not only through proclamations, the fundamental right to ne bis in idem.

At the same time, it cannot fail to take into account a necessary reflection, regarding problems which have repeatedly emerged of compatibility between the obligation to comply with the ECtHR and the legal tradition on which the national criminal law (first, and then the tax law) is based (Scaroina, 2015, p. 2922). ${ }^{8}$ While waiting for the legislator to take action, the national judges could have derogated from one of the founding values of our democratic system (through recourse, for example, to an extensive interpretation of Art. 649 of the Criminal Code) in the perspective of the maximum guarantee of fundamental rights.

Among the thousands of doubts and uncertainties that still permeate the ground of the double track and its relations with the prohibition of bis in idem, all that remains is to identify the only solutions that seem to exist, in a hypothetical and (perhaps too much) optimistic perspective.

To achieve this possible 'way forward', it is considered necessary to briefly go over the different approaches put in place by the Constitutional Court, since they allow us to understand how the supranational norm affects the national one.

6 In which it considers that "the hermeneutic chaos that transpires from the decisions of national courts is first and foremost the child of the guilty absconding of the legislator, increasingly concerned to respond, invariably with the sole instrument of criminal sanction, to the changing and contingent security demands of the citizens, coagulating and at the same time interpreting the social consensus in an instrumental way and directing it towards more and more well-defined types of enemies".

7 Which had indeed hoped that the Consulta would take the opportunity (relating to the question raised by the Court of Monza) to intervene decisively as had been done by the Conseil Constitutionnel in France. The latter declared, in fact, the constitutional illegitimacy of the double track, "qualifying as disproportionate the combination of administrative and criminal penalties for the Declaration of Human and Individual Rights of 1789, which requires the legislature to provide only for penalties that were strictly and necessary".

8 Widely on the point Scaroina which highlights just how the principle of legality (present in the ECtHR as 'inviolable core right') is understood by the Strasbourg Court "in its more limited meaning of knowability and, above all, predictability of decisions, being instead (...) the reservation of law extraneous to the conventional legal tradition and the granitic coverage of art. 7 ". 
First, to draw conclusions (and therefore to establish starting points) on the national tax system and the related problems discussed so far, it can be argued that:

- the formally administrative but essentially criminal sanction cannot be cumulated with the criminal sanction imposed for the crime envisaged concerning the same concrete fact;

- the relationship between the proceedings relating to the application of the first and the proceedings relating to the application of the second is regulated by their time scale, i.e. the rule of prevalence of the proceedings that end first in a sort of race against time applies: once one of the two proceedings has been defined, the other may not be initiated, and if it is pending it must in any case stop, without ever ending, let alone lead to the imposition on the same person of a second sanction that can be cumulated with the one already paid;

- the result is that the system outlined in Articles 19, 20 and 21 of Legislative Decree 74/2000, which focuses on the application of the principle of specialty, the double-track rule and the mechanism of linking the acts of definition of the proceedings that take place in administrative and criminal proceedings, is certain and manifestly incompatible with the Community regulations.

Now, the Constitutional Court has initially extended the scope of the rule - as provided for in the literal data - to make it applicable not only to the case of a sentence or criminal decree of conviction that has become definitive, but also to that in which a new criminal trial is brought against the person against whom another proceeding is simply pending. This shows that there are no reasons in principle to oppose an extensive reading of the code of conduct.

On the other hand, the Judge of Laws has provided some indications relevant to this reasoning, although in the context of a ruling of inadmissibility of the constitutionality questions raised by various referring judges. Inter alia, the Constitutional Court - called to intervene such as to declare the constitutional illegitimacy of Article 649 of the Criminal Code ("in so far as it does not provide for the applicability of the prohibition of a second trial to the case in which the defendant has been tried, by irrevocable measure, for the same fact, in an administrative procedure for the application of a sanction which must be recognized as criminal by the Convention for the Protection of Human Rights and Fundamental Freedoms and its Protocols") - did not show a discouraging upstream attitude about this possibility. This is demonstrated by the fact that it has incidentally highlighted the existence of a 'structural violation' by the Italian legal system of the prohibition of ne bis in idem, at least in the area of sanctions relating to the financial market, already the subject of the Grande Stevens ruling.

At the same time, the Court was also unable to rule on several questions, based on the finding that the application was inadmissible, given the uncertainties expressed by the referring court itself. 
In particular, in the judgment at issue, the referring Court maintains that "the acceptance of such a question would give rise to uncertainty as to the type of response to penalties - administrative or criminal - which the system relates to the occurrence of certain types of conduct, based on the random circumstance of the procedure defined more quickly".

It is therefore clear that the perplexities expressed therein do not seem insurmountable, so much so that it is reasonable to assume that, faced with a better formulated question, the Constitutional Court could in the future pronounce on the constitutional legitimacy of the Art. 649 of the Penal Code, as read in the European guidelines.

In fact, based on the above-mentioned statement, this situation ${ }^{9}$ is precisely the one outlined by the sentence in a comment. Therefore, should this situation occur, far from raising doubts, it would be entirely consistent with the guidelines expressed by conventional jurisprudence. On the other hand, the possible violations of other constitutional regulations, to which the same order of remittance refers, do not seem to be acceptable, precisely in consideration of the essentially criminal nature of the tax sanctions.

Therefore, from the writer's point of view and in contrast with many opinions, the suitable solution to overcome the contraindications proposed in the tax sector can be found in the possibility of supporting the interpretative adaptation of the system based on Art. 649 c.p.p. to the guidelines manifested by the ECtHR, in such a way as to render our system conform to them without the need for positive interventions by the Legislator.

In this sense, although it is true that the Court of Cassation, in a similar case, considered the question of the constitutional legitimacy of Article 649, Code of Criminal Procedure (which had been requested based on the ne bis in idem provided for by the ECtHR) as unfounded, it is also true that this groundlessness was raised only for the acknowledged non-criminal nature of the sanction provided for by Article 649. The article 116, para. 8, letter a), Law no. 388 of 23 December $2000,{ }^{10}$ such as to exclude a conspiracy with the crime of failure to pay the social security withholding tax referred to in Article 2 of Law no. 638/1983. From such a perspective, it would be evident the reinforcement of the thesis that, by now, the conventional norm, as univocally interpreted by the ECtHR, constitutes the only reference parameter in the matter of ne bis in idem, to which the code forecast is obliged to adapt.

Again, in a more recent speech on the same issue, the Constitutional Court - although it has once again called on the legislature to regulate the issue directly to "remedy the frictions that the so-called double-track system generates between the national system and the ECHHR" - has enhanced the criteria

9 I.e. the situation in which the judge of the trial that starts second is obliged to stop in order not to violate the ne bis in idem

10 This provides that 'persons who fail to pay the contributions or premiums due to social security and welfare management within the prescribed period [...] shall [...] pay a civil penalty, yearly, equal to the official reference rate plus 5,5 points'. 
developed by the A and B v. Norway judgment without, however, solving the sense just argued.

The Court reiterates that Article 649 of the Criminal Code "applies only to criminal matters in the proper sense" and maintains that "in the absence of a declaration of constitutional illegitimacy, the forecast code is not able to regulate the case in question". So, what consequences could this have? From writer's point of view, the reference to the criteria elaborated in $A$ and $B$ case would be valid, but only to the extent that they allow the combination of the two criminal and administrative sanctions. In the opposite hypothesis, i.e. where such a cumulation is contrary to the principle of ne bis in idem as elaborated by the ECtHR, then the reconstruction of the scope of the principle by the latter would not be able to comply with the internal provision and would, therefore, cease to be effective internally until the legislator or the Constitutional Court itself intervenes, alternatively, with a declaration of constitutional illegitimacy of the code.

Secondly - looking at the repercussions (and trying to imagine the ones that will still exist) that, on such proceedings, the judgment of the ECtHR has brought - in the opinion of the writer, it seems necessary to point out that all the reasoning developed by the Grand Chamber, in support of the assertion that in the present case there is no violation of Art. 4, Prot. 7, moves from the preliminary consideration that the principle of ne bis in idem does not exclude, a priori (and subject to compliance with certain conditions), that individual States adopt regulatory systems characterized by a double track of sanctions (administrative and criminal).

As is sufficiently clear from the judgment in question, however, this regulatory option can be compatible with the ne bis in idem principle only and exclusively when there is - first and foremost - a prerequisite: in the system taken into consideration, the two sanctions (criminal and administrative) must pursue different and complementary purposes and - in particular - the criminal sanction must be provided, alongside the administrative one, for the punishment of acts of tax evasion that do not end with the mere non-payment of the tax but are instead connoted by an additional component and, specifically, by fraudulent conduct.

In other words, the first requirement that the ECtHR requires in order to exclude a breach of Art. 4, Prot. 7, ECHR is that, as in the case of the two Norwegian citizens, the celebration of a dual procedure for the same fact is derived from the need to prosecute the taxpayer, also in criminal (and not only administrative) proceedings, concerning the fraudulent conduct that the taxpayer has committed, which is an additional element to the non-payment of the tax.

It seems, in short, untenable an interpretation which, while admitting the lack of difference between a formally criminal sanction and a sanction (otherwise called) - which, however, has the substance of the latter - and while recognizing the pervasiveness of the supranational jurisprudence which has founded such an assimilation, stops in the face of the literal tenor of the internal disposition and from this, gives rise to the need for intervention by the legislator or a 
demolition ruling by the Constitutional Court. If the ECtHR itself has conclude that the 'living law' referred to above has shaped the letter of Art. 4, Prot. 7, $E C H R$, an identical effect must also be possible about the internal provision.

On closer inspection, moreover, in other contexts our Supreme Court has not hesitated to admit such an interpretation, arguing that the domestic court must interpret the domestic norm following the ECtHR 'as it lives in the caselaw of the European Court'.

On the other hand, different reasoning would lead to giving the individual states party to the EDU Convention considerable discretion in grading the applicative effects of the conventional rules shaped by supranational jurisprudence. Such a possibility would, of course, be incompatible with the objectives of the Convention itself and, on the contrary, would run counter to the uniform function attributed to the latter.

It would justify, in other words, a 'leopard's eye' application of the principles developed by the ECtHR, now admitting their influence on the interpretation of the domestic provision (as concerning the rules of due process under Article 6, ECHR), now denying it as in the present case.

While being aware, to date, of the rejection by the Italian Constitutional Court and the Italian Supreme Court itself, from the writer's point of view the solution just proposed would have the merit of guaranteeing the conformity of our system to conventional obligations in an automatic way, without mediation by internal bodies, with the related expansion of time.

In this sense, such an approach would also be consistent with the requests coming from the neighbouring area of European Union law - in which it has been argued that the prohibition of ne bis in idem enshrined in Article 50 of the Charter of Fundamental Rights of the European Union - is also valid concerning the sanctions formally called tax sanctions but which are endowed in substance with such a function as to assimilate them to criminal ones.

There is no doubt that even in the European context, as has been pointed out repeatedly in this contribution, there is no lack of ambiguity. In fact, contradicting the Advocate General's requests in the Menci case the European Court of Justice has recently admitted the cumulation of criminal and administrative sanctions for failure to pay withholding taxes (Article 10-bis of Legislative Decree 74/2000 and Article 13 of Legislative Decree 471/1997), limiting itself to stating that it is legitimate to the extent that there is "coordination aimed at reducing to what is strictly necessary the additional burden that such cumulation entails for the parties concerned".

Such a move is in the wake of the prudential approach - which is also reflected in the $A$ and $B$ judgment, which after the very clear positions taken in the first judgments - softens the absoluteness of the ne bis in idem principle since it is more likely to come under political pressure from the Member States. Compared to the context outlined by the ECtHR, the position of the Court 
of Justice is less clear, justifying the view of those who see a disconnection between the case-law of the former and the latter.

However, the Menci judgment, in admitting the cumulation of penalties which it considers to be consistent with the Union's objective of effectively combating VAT evasion and fraud, seems to suggest an approach not unlike that of the $A$ and $B$ v. Norway judgment, the results of which are expressly referred to by the Luxembourg courts. It is stated that, in the meantime, an accumulation of sanctions conforms with Article 50 EUCFR, where not only does the overall severity of the sanction not exceed a limit of severity commensurate with the seriousness of the offense, but also where there is effective coordination between the two proceedings, in terms of both the functions pursued and the procedural burden.

Again, as pointed out above, the discrepancy between the jurisprudence of the ECtHR and the European Court of Justice has been particularly evident in terms of the principle of homogeneity. The approach of the Court of Luxembourg to the Art. 52(3) is useful to highlight that, in the Åkerberg case, the Court kept silent on the case-law of the ECtHR and, implicitly, invoked the application of Engel's criteria, and then placed the matter in the hands of the national court to determine the criminal nature (or otherwise) of the surcharge. On closer inspection, it never specified that these criteria were developed in the case-law of the Court of Luxembourg itself, but it directly mentioned the Bonda case, which expressly refers to the case-law of the Court of Strasbourg and the Engel criteria. The case was received by the Court in 2010, which means that, following the entry into force of the Charter and because of Poland's opt-out protocol, the Charter was not invoked.

The fact that the European Court of Justice did not mention the case-law of the ECtHR in the Akerberg case gave rise to different views on its actual intentions. On the one hand, it was argued that the Court wanted to give a specific - more limited - meaning to the homogeneity clause in Article 52(3) of the Charter, thus avoiding mentioning the Convention. On the other hand, it was also argued that the Åkerberg case "skilfully and indirectly aligns the criteria of the European Court of Human Rights for determining a criminal charge with those of the Charter" and that "the Charter has reinforced the impact of the ECtHR". The latter opinion seems to be more appropriate and in line with the judgment since, while only citing the Bonda case, the Strasbourg Court indirectly referred to the ECtHR in the Engel case.

It would seem, therefore, that from the conclusions of the Akerberg case the alignment of the European Court of Justice with the view of the ECtHR is inferred, which would lead one to think that the European Court of Justice has never directly addressed the issue of Art. 52(3) in the Åkerberg case, but has indirectly used the Engel criteria.

The assertion made by some professors (Groussot-Ericsson, 2016, p. 73; Lock, 2009, pp. 383-384) that the Court in Luxembourg decided to adopt a 'minimalist interpretation' of Art. 52(3) in the Åkerberg case seems correct. 
This means that to maintain a certain distance from the ECtHR, the CJEU did not explicitly address its case law or any other issue related to the Convention but preferred to adopt the Engel criteria silently, making sure, more than anything else, that the focus was entirely on the Charter and issues concerning the legal order of the European Union and not on possible disconnections between the Courts since the ultimate aim is and must always be the correct application of the rule.

All that has been stated so far, highlights, even more, that the acceptance of the solution proposed therein would be the easiest - and at the same timeless traumatic - way to avoid the protection gap that, rebus sic stantibus, our sanctioning system creates against a taxpayer who is the author of a tax illegal conduct. It would take the issue away from the inevitable long timescale of the legislator's action (which has been required for years) and, at the same time, would not require a demolition intervention by the Constitutional Court.

Ultimately, it is a matter of taking note of the fact that supranational bodies have determined - in this as in many other areas - a profound modification of concepts and institutions proper to national systems, so much to make it more than necessary to re-read the internal rules based on the (now increasingly urgent) requirements that living law, not only national but also supranational, suggests.

Perhaps, even, in this case, a more intense and fruitful dialogue between our Supreme Courts and supranational jurisdictions - which has already proved effective regarding the well-known Taricco case - would make it possible to prevent misunderstandings and would open the way to forms of interpretation of internal norms in a systematic key about the complex of supranational principles and values that now permeate, and in some way dutifully define the national order.

As argued since the beginning of this contribution, "rien n'est une excuse pour agir contre ses principes". ${ }^{11}$ There are superior rules whose respect is essential to safeguard the interests of all. Rules which, if violated, would undermine even more the current social landscape, since their violation would necessarily bring harmful consequences for citizens. Rules without which the foundations of today's society would fail.

The ne bis in idem principle is an undoubtedly part of these rules and that is why, at this moment in history more than ever, a firm point must be made.

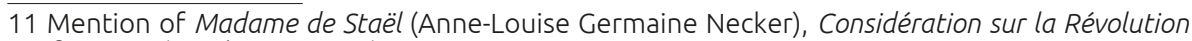
française (posthume, 1818). 


\section{References}

Amatucci, A. (2016). Il sistema delle sanzioni amministrative tributarie secondo il diritto UE ed il diritto internazionale. In G. Di Martino, ed., Trattato di diritto sanzionatorio tributario. Milan.

Attard, R. (2011). The Classification of Tax Disputes, Human Rights Implications. In G. Kofler et al., eds., Human Rights and Taxation in Europe and the World. IBFD.

Attard, R. (2017). The ECtHR's Recent Tax Judgments on the Non Bis in Idem Rule. EC Tax Review, 6, pp. 335-338.

Autexier, C. (1987). L'hétérogénéité du droit communautaire. Revue internationale de droit compare, 34(2), pp. 337-372.

Baker, P. (2000). Taxation and the European Convention on Human Rights. British Tax Review. At <http://www.fieldtax.com/wp-content/ uploads/2015/04/BTR-2000-4-211-377-Taxation-and-the-EuropeanConvention-on-Human-Rights.pdf>, accessed 20 August 2019.

Baker, P. (2001). The Decision in Ferrazzini: Time to Reconsider the Application of the European Convention on Human Rights to Tax Matters. Intertax, 29(11).

Barbard, C. (2008). The "Opt-Out" for the UK and Poland from the Charter of Fundamental Rights: Triumph of Rhetoric over Reality? In S. Griller and J. Ziller, eds., The Lisbon Treaty, 11. European Community Studies Association of Austria Publication Series.

Bering, L. (2011). Does the EU Charter of Fundamental Rights Threaten the Supremacy of Community Law? Jean Monnet Working Paper, 4(1), pp. 79106.

Bricola, F. (1973). Voce «Teoria generale del reato». Novissimo Digesto Italiano, 19, p. 15.

Brokelind, C. (2013). Case note on Åkerberg Fransson (case C-617-10). European Taxation Journal, 53(6). IBFD.

Busson, E. (2003). Il principio di specialità. Nannacci e d'avirro. La riforma del diritto penale tributario.

Ceci, L. (2017). Actualités 2017 en droit pénal fiscal. In Le droit fiscal en Belgique, Coll. Les ateliers des FUCam. Limal: Anthémis, pp. 543-605.

De Vries, M. (2015). The EU Charter of Fundamental Rights as a Binding Instrument: Five Years Old and Growing. Bloomsbury Publishing, p. 168.

Del Mar, D. (2002). España, informe sobre el principio non bis in idem y la concurrenciade jurisdicciones entre los tribunales penales españoles y los tribunales penales internacionales. Revue internationale de droit pénal, 73, pp. 873-899.

Delmas, M. (1987). Le matière pènale au sens de la Convention européenne des droit dè l'homme, flou du droit pènale. Rèvue Scientifique Criminologie, p. 820.

Fatta, C. (2017). Il nuovo volto del ne bis in idem nella giurisprudenza della Grande Camera e la compatibilità con il doppio binario sanzionatorio in materia tributaria. Giurisprudenza Penale, p. 23.

Gallo, F. (2017). Il ne bis in idem: un esempio per riflettere sul "ruolo" delle Alte Corti e sugli effetti delle loro pronunzie. Rassegna tributaria, 4, p. 915.

Giovannini, P. (2016). Il principio del ne bis in idem sostanziale. In P. Giovannini, ed., Trattato di diritto sanzionatorio tributario. Milan. 
Groussot, E. (2016). Ne bis in idem in the EU and the ECHR Legal Orders: A Matter of Uniform Interpretation. In B. V. BOCKEL, ed., Ne bis in idem in EU Law. Cambridge: Cambridge University Press, p. 73.

Groussot, O. (2014). Clarifying or Diluiting the Application of the EU Charter of Fundamental Rights? The Judgements in Åkerberg Fransson and Melloni from 26 February 2013. In C. Brokelind, ed., Principles of Law: Function, Status and Impact in EU Tax Law (IBFD), p. 62.

Harris, O. et al. (2009). Law of the European Convention on Human Rights. Oxford, p. 204.

Kofler, P. (2011). General Report. In P. Kofler et al., eds., Human Rights and Taxation in Europe and the World. IBFD, pp. 4-8.

Koning, F. (2013). Le principe non bis in idem et la loi du septembre 2012 instaurat le principe una via dans la répression des infractions fiscales. J.L.M.B., 10, pp. 581-585.

Lecoca, A. (2016). Principe non bis in idem: vers l'esquisse d'une standardisation de l'Una via procédural - experience belges et française. RPS-TRV, 6, pp. 645-668.

LeDain, A. Y. (2017). Précisions apportées par la Cour européenne des Droits de l'Homme quant à l'application du principe 'non bis in idem'. Dalloz, 38, pp. 6-8.

Lenaerts, S. (2001). The Charter and the Role of the European Courts. Maastricht Journal of European Law, 8, p. 90.

Lock, T. (2009). The ECJ and the ECtHR: The Future Relationship between the Two European Courts. The Law and Practice of International Courts and Tribunals, 8(3), pp. 383-384.

Maisto, G. (2017). Cases involving the application of the ne bis in idem principle. In P. Pistone et al., eds., Recent developments in direct taxation, pp. 107-116.

Russo, P. (2016). Il principio di specialità e il divieto del ne bis in idem alla luce del diritto comunitario. Rivista di diritto tributario, 1, p. 24.

Sacchetto, C. (2015). Sanzioni tributarie e CEDU. Rassegna tributaria, p. 483.

Scaroina, E. (2015). Costi e benefici del dialogo tra Corti in materia penale. La giurisprudenza nazionale in cammino dopo la sentenza Grande Stevens tra disorientamento e riscoperta dei diritti. Cassazione penale, pp. 2920-2921.

Seidmann, S. (2000). Il diritto al silenzio aiuta gli innocenti: A Game-Theoretic Analysis of the Fifth Amendment Privilege. Harvard Law Review, 114, p. 430.

Slater, D. et al. (2009). Competition Law Proceedings before the European Commission and the Right to a Fair Trial: No Need for Reform? European Competition Journal, 5(1), pp. 97-143.

Van Bockel, W. B. (2010). The Ne bis in idem Principle in Eu Law. Leiden: Kluwer Law International. At <https://cadmus.eui.eu/handle/1814/14641>, accessed 10 September 2019.

Vervaele, J. (2014). European Criminal Justice in the Post-Lisbon Area of Freedom, Security and Justice. At <http://eprints.biblio.unitn.it/4399/1/ COLLANA_QUADERNI_VOLUME_5_VERVAELE_FORNASARI_ SARTORI_02.09.2015.pdf>, accessed 10 August 2019.

Vervaele, J. (2013). Ne bis in idem: Towards a Transnational Constitutional Principle in the EU? Utrecht Law Review. At <https://www.utrechtlawreview. org/articles/abstract/10.18352/ulr.251/>, accessed 12 September 2019.

Vogel, K. (1988). The justification for taxation: a forgotten question. The American Journal of Jurisprudence, 33(1), pp. 19-59. 
Vozza, D. (2013). I confini applicativi del principio del ne bis in idem interno in materia penale: un recente contributo della Corte di Giustizia dell'Unione Europea. Diritto penale contemporaneo - Rivista trimestrale, 3, p. 294.

Wattel, P. J. (2016). Ne Bis in Idem and Tax Offences in EU Law and ECHR Law. In B. Bockel, ed., Ne Bis in Idem in EU Law. Cambridge: Cambridge University Press, pp. 167-217.

Whitaker, S. (1992). Schengen Agreement and its Portent for the Freedom of Personal Movement in Europe. Georgetown Immigration Law Journal, 1, p. 191.

Young, A. (2018). Four Reasons for Retaining the Charter Post Brexit: Part 1 - A Broader Protection of Rights. At <https://ohrh.law.ox.ac.uk/four-reasonsfor-retaining-the-charter-post-brexit-part-1-a-broader-protection-of-rights/>, accessed 1 September 2019.

Zetsche, D. (2009). Hidden Ownership in Europe: BAFin's Decisions in Schaeffler v. Continental. European Business Organisation Law Review, 10(1), pp. 115147.

Zugaldia, E. (2001). La responsabilidad criminal de las personas jurídicas en el derecho penal español. In V. M. Quintero and O. Morales Prats, eds., El nuevo Derecho penal español. Pamplona: Aranzadi, p. 885. 